DOI: https://doi.org/10.24867/07KG02Mitrovic

\title{
УВОЪЕЊЕ И РАЗВОЈ КАТАСТАРСКИХ ЕВИДЕНЦИЈА НА ПОДРУЧЈУ ПОЛИТИЧКЕ ОПШТИНЕ РОГАТИЦА
}

\section{ESTABLISHMENT AND DEVELOPMENT OF CADASTRAL RECORDS IN THE TERRITORY OF THE POLITICAL MUNICIPALITY OF ROGATICA}

\author{
Јелена Митровић, Горан Маринковић, Факултет техничких наука, Нови Сад
}

\section{Област - ГЕОДЕЗИЈА И ГЕОМАТИКА}

Кратак садржај - Овај рад је резултат истраживања на тему катастарске евидениије у Републици Српској, са посебним освртом на ток развоја катастарских евиденција у општинама Рогатица и Фоча. C обзиром да је тежња катастра прелазак на јединствену евидениију, основни ичиљ истраживања био је анализа стања досадашње евидениије као основе за даљи развој.

Кључне ријечи: Kaтастар, премер

Abstract - This paper is the result of research on cadastral records in Republika Srpska, with particular reference to the development of cadastral records in the municipalities of Rogatica and Foca. Considering that cadastral aspiration is a transition to a single record, the primary goal of the research was to analyze the state of the records to date as a basis for further development.

Keywords: Cadastre, survey

\section{1. УВОД}

Потреба за евиденцијом земљиштва постојала је још од времена старих Римљана. Може се рећи да је та потреба често била посљедица великих освајања територије. С обзиром на то, сматра се да катастар као велика база података о земљишту има коријене још у XV вијеку. У складу са законима који су били актуелни у појединим периодима, прво се као јединствена база података о земљишту, објектима и носиоцима права на њима јавља Катастар некретнина. Након тога јавља се Катастар непокретности. Са развојем технологије и све распрострањенијом употребом рачунара и различитих софтвера, успоставља се и електронска база података. Такође, врши се дигитализација старих, аналогних планова.

Предмет истраживања у овом раду је стање катастра у општинама Рогатица и Фоча са освртом на историјски развој, те промјене које су се временом дешавале у катастру. Акценат је стављен на тежњу за модернизацијом евиденције података о земљишту, објектима и носиоцима права на њима, како би рад у катастру био олакшан и убрзан у што већој мјери.

\section{НАПОМЕНА:}

Овај рад проистекао је из мастер рада чији ментор је био доц. др Горан Маринковић.

\section{2. КАТАСТАР - ОСНОВНИ ПОЈМОВИ}

Катастар преставља јавни регистар података о земљишту који су се користили у разне сврхе као што је израда земљишних књига или као основа за опорезивање становника.

\section{1. Катастар непокретности}

Катастар непокретности, наиме, представља јавну евиденцију која садржи информације о непокретностима и стварним правима над њима [1].

\subsection{1. Оснивање катастра непокретности}

Оснивање катастра непокретности подразумијева поступак излагања на јавни увид података о непокретностима и стварним правима на истим. Циљ излагања на јавни увид је да се правни подаци (подаци из земљишне књиге или књиге тапија) и фактички подаци (подаци из катастра земљишта) изложе грађанима на увид и ускладе. У том поступку формира се база података катастра непокретности која обједињује те двије врсте података [2].

\section{3. ИСТОРИЈСКИ РАЗВОЈ КАТАСТРА У БИХ}

Коријени геодетске струке сежу још у доба Римљана. Прве евиденције земљишта на просторе Босне и Херцеговине као обавеза уведене су у доба Османског царства. За то вријеме везују први закони везани за катастар, тј. за евиденцију земљиштва. Након Османлија, на власт долази Аустроугарска која убрзо приступа усавршавању катастра (успоставља се први премјер, тригонометријска мрежа, катастарско класирање и бонитирање земљишта, израда планова, итд.) Катастар у доба Аустроугарске доживљава велики успон. Ствара се двојна евиденција, катастар земљишта и земљишна књига. Први премјери који су спровођени у вријеме Југославије ослањали су се на успостављену аустро-угарску триангулацију. Актуелне реформе везане за катастар непокретности у Републици Српској на снази су од 2012. године [3].

\section{4. СТАҢЕ КАТАСТРА НА ПОДРУЧЈУ ОПШТИНЕ РОГАТИЦА КРОЗ ИСТОРИЈУ}

Први премјер на териоторији општине Рогатица извршен је у периоду Аустро-Угарске власти. Наиме, као што је у претходном тексту наведено Војно-географски институт из Беча је у року од 1880 . до 1884. год. извршио графички премјер на терито-рији БиХ, па тиме и у општини Рогатица. Том приликом формирана је земљишна књига и катастар земљи-шта [3]. 


\section{1. Период послије Другог свјетског рата 1945- 2005}

С обзиром да је земљишна књига, како је претходно наведено, уништена у Другом свјетском рату, те да су једини подаци којима се тада располагало били подаци из Катастра земљишта, дошло је до знатних проблема. Првенствено, до проблема је дошло када је у питању опорезивање прихода од земљишта, тј. дешавала се неравномјерност пореског оптерећења. То је узроковало потребу за увођењем драстичних измјена. Тако је 1954. године као пореска основица уведен катастарски приход.

У периоду од 1948. до 1952. извршена је ревизија катастра земљишта за подручја у којима је постојала неусаглашеност истог са стварним стањем. Године 1953. на основу процјене површина парцела и катастарског класирања земљи-шта израђен је пописни катастар који је служио као привремено рјешење за тренутну ситуацију. Форми-ран је катастарски операт базиран на аустро-угарском премјеру [3].

\section{2. Увођење јединствене евиденције}

Након што је 1991. године формиран операт настала су ратна збивања, која су спријечила наставак радова на формирању катастра некретнина. Може се рећи да су до 1992. године једини подаци везани за катастар могли да се пронађу у катастру земљишта, с обзиром да је земљишна књига уништена. Након што је рат окончан катастар је радио у оквиру опште службе општине Рогатица, а недуго затим и као Подручна јединица у оквиру Републичке управе за геодетске и имовинско-правне послове.

Подаци који су у то вријеме кориштени и даље су били подаци из катастра земљишта. Настављено је излагање у започетим општинама. Тачније, исправљале су се грешке, формирали елаборати, а упоредо је формирана и електронска база података, уносом истих у рачунар. На тај начин је формирана база података за општине у којима је завршено излагање. Коначно ступање на снагу катастра некретнина за 27 катастарских општи-на десило се средином 2001. године, након доношења рјешења од стране Републичке управе за геодетске и имовинскоправне послове. У новембру 2004. године РУГИПП је образовала комисију за излагање на јавни увид података о некретнинама и утврђивање права на некретнинама за катастарске оптшине Рогатица I и Рогатица II

\section{5. СТАҢЕ КАТАСТРА У ОПШТИНИ РОГАТИЦА 2005-2019}

Од 2005. године активности катастарских подручних јединица, па тако и ПЈ Рогатица, сконцентрисане су на обнову и одржавање катастра непокретности (Слика 1). С обзиром на технолошки развој и све већу употребу рачунара у свим сферама пословања, временом се јавила потреба за дигитализацијом старих аналогних катастарских планова. То је, свакако, представљало велики задатак за запослене у геодетској служби. С обзиром на тачност којом катастар мора да располаже с једне стране, и релативно лошег стања геодетских планова, с друге стране дигитализација је представљала велики изазов. Посљедња обнова премјера била је 2000. године. Од тада до данас користи се премјер из тог периода, изузев градске зоне коју обухвата КО Рогатица 1 на којој је извршен премјер 2019. године.

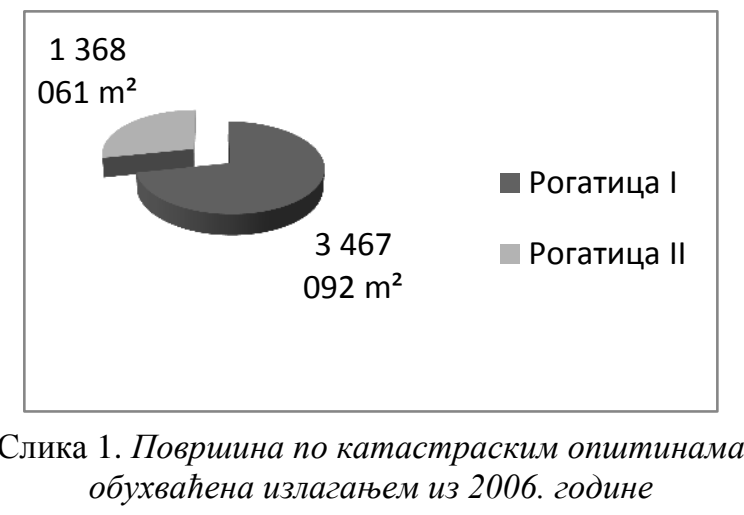

\section{1. Дигитализација катастарских планова}

ДГП се израђује на основу техничких правила датих Правилником, методама снимања детаља и у размјери којае је у складу са законом. Основни елеменат ДГП-а је објекат и то тачкасти, линијски, површински и текстуални [2]. Објекти имају просторне, тематске, квалитативне и временске атрибуте, као и јединствене идентификаторе [4]. Поступак дигитализације у општини Рогатица, углавном је заснован на секундарном методу прикупљања података, тј. на скенирању постојећих аналогних планова. Аналогни планови су скенирани скенером ВИДАР произвођача, резолуцијом скенирања 400 тачака по инчу и то у растерском .tif формату. Након скенирања, контролом квалитета, утврђено је да је исто урађено у границама толеранције. Општина Рогатица има 31 катастарску општину и за сваку од њих је урађен дигитални катастарски план.

\section{2. Нови катастар непокретности}

Као што је већ наведено у претходном дијелу овог рада, први катастар некретнина успостављен је до 2005. године. Исти је имао низ недостатака, а првенствено није садржао податке за катастарске општине Рогатица 1 и Рогатица 2, које су катастарске општине градског типа и обухватају ужи градски дио. С обзиром на то и на потребу за тачнијим подацима, као и за ажурирањем постојећих, РУГИПП је 2015. године донијела одлуку да се изврши ново излагање у оптштини Рогатица, те да се оснује нови катастар непокретности. Излагање података на јавни увид завршено је 2019. године за све катастарске општине. Наиме, завршено је оснивање катастра непокретности у општини Рогатица, с тим да исти још увијек није усвојен.

\section{3. Катастар водова}

Катастар водова као посебна цјелина у области катастра није основан, иако за то постоји адекватна законска основа. Према наводима запослених, постоје индиције да ће пројекат оснивања катастра водова ускоро да ступи на снагу, мада још увијек нису предузете конкретне мјере. 


\section{6. СТАЊЕ КАТАСТРА НА ПОДРУЧЈУ ОПШТИНЕ ФОЧА КРОЗ ИСТОРИЈУ}

Први попис земљишта везује се за име султана Сулејмана Великог. Попис земљишта из тог периода се зове Грунтовницом. Попис Херцеговине проведен је 1515. године, чији су подаци дио фочанског хаса из тог времена. По тадашњем закону катастар се морао ажурирати сваке три године.

Први премјер извршила је Аустроугарска војска 1905. године, када је успоста-вљена прва потпуна евиденција земљишта. На основу премјера и других података израђени су катастарски планови и катастар земљишта. Рађени су планови у размјери 1:6250, изузев густо насељених мјеста у градова који су се израђивали у крупнијим размје-рама. Општина Фоча je, као и остатак државне територије била обухваћена аустроугарским премјером. До Другог свјетског рата одржаван је премјер као и земљишна књига. У току Другог свјетског рата земљишна књига у општини Фоча бива уништена, као и у многим другим општинама, међу којим је и Рогатица.

Одржавање катастра и земљишне књиге није вршено од 1945. до 1953. године. С обзиром да је у ратном и послијератном периоду узурпација попримила абнормалне размјере, а и друштвена своји-на није била заштићена, било је потребно израдити нови катастар земљишта. Да би се претходно наведени проблеми што прије превазишли, одлучено је да се изради пописни катастар. На основу литогра-фских копија аустроугарских планова које је посје-довала Републичка геодетска управа, у периоду од 1951. до 1953. Године, урађен је пописни катастар за општину Фоча. Теренски радови се су обављали по срезовима. Број ангажованих геодетских стручњака зависио је од величине среза [3].

\section{1. Премјер у периоду Југославије}

Без обзира што је Уредба о катастру земљишта предвиђала да се уради премјер у року од 5 година након завршеног пописног катастра, први премјер је рађен тек 1978. године. Исти је обавио „Геодетски завод Босне и Херцеговине".

На основу премјера општина Фоча подијељена је на 58 катастарских општина. Подаци премјера послужили су изради катастарског операта. За снимљено подручје је завршен премјер, катастарско класирање и бонити-рање земљишта. У одоварајућим размјерама за сни-мљено подручје, израђени су катастарски планови. Исте године извршено је аерофотограметријско снимање територије општине Фоча. Аерофотагра-метријом су обухваћене све катастарске општине.

У периоду од 1978. до 1980. године успостављена је полигонска мрежа на територији општине Фоча. Иста се ослањала на тригонометријску мрежу аустроугарског премјера. Године 1982. извршено је прво излагање на јавни увид података о непокретностима ради оснивања катастра некретнина. Том приликом изложено је на јавни увид 58 катастарских општина. За формирање података за излагање на јавни увид кориштени су сви постојећи извори података, односно катастар земљишта, пописни катастар, те планови и карте.

\section{7. АКТУЕЛНО СТАҢЕ КАТАСТРА У ОПШТИНИ ФОЧА}

Дигитализација је, као и у већини општина, заживјела и у Фочи, али тек од 2010. године. Поступак дигитализације је рађен секундарним методама. Као и у општини, Рогатица, и Фоча је имала проблем због чињенице да су земљишне књиге уништене у току ратних збивања, те је један вид контроле био елиминисан. На сљедећем дијаграму (Слика 2) приказан је број захтјева за исправку грешке у периоду од 2015. до 2018. године.

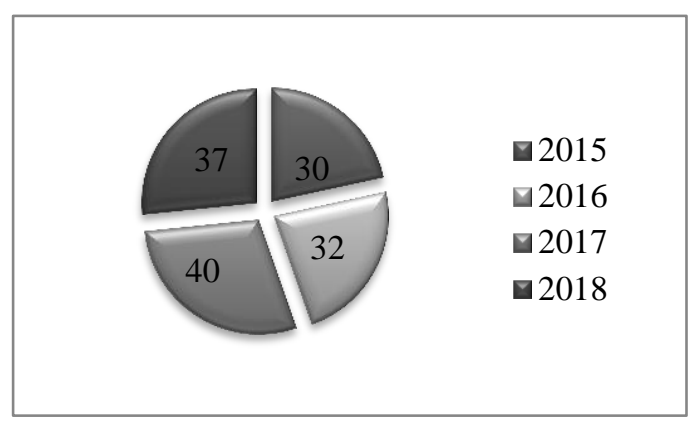

Слика 1. Број захтјева за исправку грешке у периоду од 2015. до 2018. године

Доношењем новог Правилника о начину оснивања и одржавања катастра непокретности Републике Српске ПЈ Фоча приступа оснивању новог катастра непокретности. Поступак излагања почео је исте године, али још увијек није у потпуности завршен. Такође, катастар непоретности није још увијек усвојен ни за једну катастарску општину са територије општине Фоча. У ПЈ Фоча веома је присутна заинтересованост становништва за вјештачења. Узрок вјештачења је, најчешће, неупућеност власника у тачно фактичко стање на парцели (парцелама). Сљедећи дијаграм (Слика 3) показује статистику о броју вјештачења на подручју општине Фоча, за период 2015-2018. године.

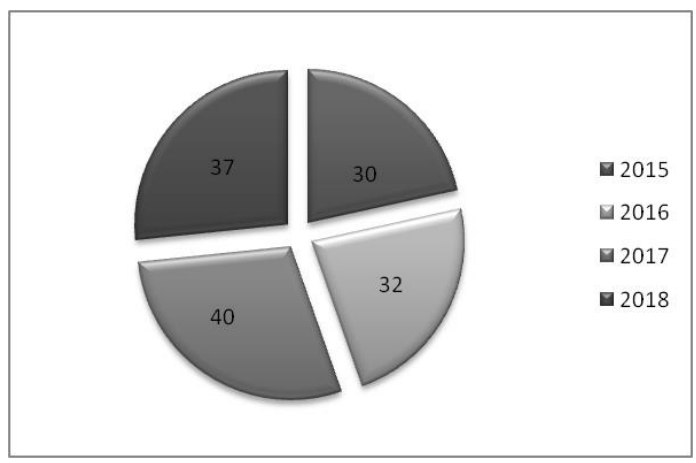

Слика 2. Број вјештачења у ПЈ Фоча у периоду 2015 2018. године

\section{1. Катастар водова}

Катастар водова у општини Фоча дјелимично је формирам 1989 године. Још увијек не постоји одговарајући софтвер који би испратио одржавање катастра водова.

\section{8. УПОРЕДНА АНАЛИЗА СТАЫА КАТАСТРА У ОПШТИНАМА РОГАТИЦА, ФОЧА И ЗВОРНИК}

Упоредном анализом двије општине које су биле предмет истраживања у овом раду и општине Зворник 
за коју су подаци преузети из рада [5], биће успостављен однос развијености и активности подручних јединица предметних општина. Потребно је нагласити да се ради о три општине које су на различитим нивоима опште развијености. Зворник, који има статус града и знатно се издваја по развијености у односу на друге двије, затим Фоча која располаже огромним природним богатством, али је ипак на љествици развијености нешто испод Зворника и на крају Рогатица као најнеразвијенија од три предметне општине.

Историјски гледано може се рећи да је развој катастра текао једнаким интензитетом у све три општине до Другог свјетског рата. Ратна збивања направила су драстичне разлике. У општинама Фоча и Рогатица земљишне књиге су потпуно уништене, док је у Зворнику исто задесило само неке катастарске општине. То је, свакако, утицало на даљи развој катастра у предметним општинама. Када је у питању оснивање катастра непокретности, статистика показује знатне разлике код предметних општина.

Рогатица, као примјерна општина у Републици Српској, завршила је излагање података на јавни увид у току 2019. године. С друге стране општине Зворник и Фоча су још увијек у почетној фази излагања података на јавни увид. На сљедећем дијаграму (Слика 4) приказан је степен завршености излагања података на јавни увид у предметним општинама, по КО.

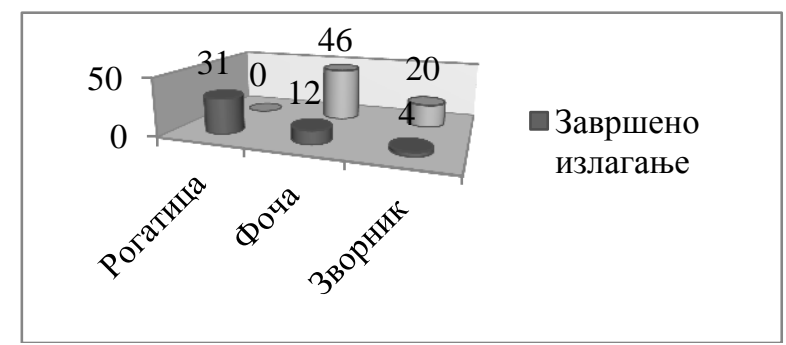

Слика 3. Степен обављености излагања података на јавни увид

Број запослених у подручним јединицама Рогатица, Фоча и Зворник у сразмјерном је односу са обимом посла. Статистика о броју решених предмета у предметним општинама приказана је на сљедећем дијаграму (Слика 5).

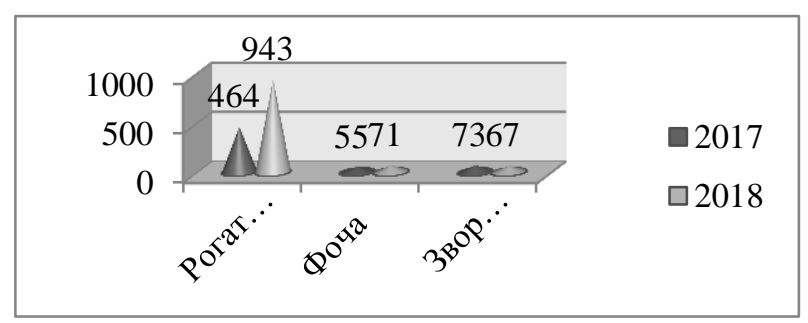

Слика 4. Број решених предмета у 2017. и 2018. години

\section{9. ЗАКЉУЧАК}

Као што је у уводном дијелу овог рада наглашено, главни циљ истраживања стања катастра у предметним општинама, па и Републици Српској уопште, био је утврђивање интензитета развоја катастра од његовог оснивања до данас кроз различита временска раздобља, упознавање са афинитетима надлежних органа ка увођењу иновација у област геодетске струке, те са интересовањем запослених да се за исте обуче и примјене их у раду. Резултат истраживања показао је, углавном позитивне резултате. Наиме, што се тиче стања катастра, показало се да је, за разлику од 70\% општина у Републици Српској, у општинама Рогатица и Фоча сасвим задовољавајуће, с обзиром на тренутни глобални ниво развијености у држави. Обје предметне општине прате континуитет у развоју. Увођење иновација кроз историју није наилазило на озбиљније препреке. Чак и чињеница да су земљишне књиге изгорјеле у току ратних збивања у обје општине није спријечила увођење нових метода нити облика пословања.

Као финални закључак може се навести да је пред Републичком геодетском управом, као и пред подручним јединицама које су биле предмет истраживања, велики задатак када је у питању унапређење квалитета и тачности података, али и увођење нових технологија у употребу, као и нових софтвера за обраду и ажурирање података. Такође, може се истаћи да је, с обзиром на ограничавајући фактор, стање катастра у подручним јединицама Рогатица и Фоча задовољавајуће.

\section{0. ЛИТЕРАТУРА}

[1] Миливојевић, Н.; Трифковић, М. Стање премера на територији политичке општине Чачак, Зборник радова ФТН 2016, 8, 1509-1512

[2] Marinković, G.; Lazić, J.; Ilić, Z. The basis for the establishment of a database of utility lines cadasterrealistic approach, Archives for Technical Sciences 2017, 17(1), 57-66.

DOI: 10.7251/afts.2017.0917.057M

[3] Бегић, М. 110 година катастра Босне и Херцеговине, Дипломски рад, Универзитет у Сарајеву, 2010.

[4] Правилник о дигиталном геодетском плану („Службени гласник Републике Српске“ број 43/04)

[5] Андрић, М.; Маринковић, Г. Стање премјера на територији општине Зворник, Зборник радова ФТН 2019, 8, 1458-1461

\section{Кратка биографија:}

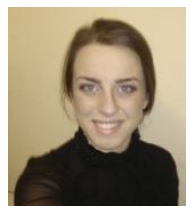

Јелена Митровић рођена је 1994. године у Рогатици. Мастер рад на Факултету техни-чких наука из области Геодезије и геоматике одбранила је 2019. године. (e-mail: jelenamitrovic244@gmail.com)

Горан Маринковић рођен је у Власеници 1968. године. Докторску дисертацију из области геодезије на Факултету техничких наука у Новом Саду одбранио је 2015. Године (e-mail: goranmarinkovic@uns.ac.rs) 